\title{
An Analysis of the Effects of Stock Market Development on Economic Growth in Kenya
}

\author{
Stephen M. Ikikii ${ }^{1} \&$ Joseph N. Nzomoi ${ }^{2}$ \\ ${ }^{1}$ Economics Department, Hacettepe University, Ankara, Turkey \\ ${ }^{2}$ Analysis and Planning Division, Kilimo Trust, Kampala, Uganda \\ Correspondence: Joseph N. Nzomoi, Analysis and Planning Division, Kilimo Trust, Plot 42, Princess Anne Drive, \\ Bugolobi, P.O. Box 71782, Kampala, Uganda. E-mail: nnzomoi@yahoo.co.uk or jnzomoi@kilimotrust.org
}

\author{
Received: August 14, $2013 \quad$ Accepted: September 22, $2013 \quad$ Online Published: October 26, 2013 \\ doi:10.5539/ijef.v5n11p145 URL: http://dx.doi.org/10.5539/ijef.v5n11p145
}

\begin{abstract}
This paper presents an analysis of the stock market development effects on economic growth in Kenya, using the gross domestic product and the two key measures of stock market - capitalization and trade volume. Empirical results indicate that variables satisfied apriori expectations, are statistically significant, and positively correlated with feed-back effects. Capitalization, trade volume and economic growth are highly positively correlated in Kenya, with capitalization and trade volume jointly explaining $91 \%$ of the variations in the economic growth, over the period under study. Further, the study found that a $1 \%$ increase in both trade volume and capitalization causes $0.025 \%$ and $0.115 \%$ increase in gross domestic product respectively. Thus, empirical evidence shows that stock market development (measured by trade volume and/or capitalization) impacts positively on the economic growth in Kenya.
\end{abstract}

Keywords: stock market development, market capitalization, economic growth

\section{Introduction}

Stock market development is of immense importance to growth. King and Levine (1993) stated that the level of financial intermediation is a good predictor of capital accumulation, productivity and economic growth, while Carlin and Mayer (2003) established the existence of a strong relationship between economic growth and the structure of the countries' financial system. The financial system provides a platform for trading innovative financial instruments such as currency exchange, equities, bonds, various derivatives like futures, swaps and options among others. This in turn helps in mobilizing the much need financial resources (capital) from surplus units to deficit units for investments in profitable projects. This helps both the private sector and governments to expand production by increasing investment and ultimately accelerating growth.

The link between growth and stock market for developed economies has been greatly researched, as the role of the financial sector in promoting growth cannot be underestimated. Stock market development is an essential component of growth as it plays an essential part in the economic theory of production and distribution. The stock market is one of the major sectors for capital formation, and it is assumed that capital accumulation can facilitate a faster rate of economic growth. The stock market in developing economies is growing very fast, and it is estimated that the Kenyan stock market is an over ten billion-dollar industry, and is the fourth largest stock exchange in Africa with respect to trading volumes, and fifth in terms of market capitalization as a percentage of Gross Domestic Product (GDP).

Kenya's economic blue print "Kenya Vision 2030" envisions "A vibrant and globally competitive financial sector driving high levels of savings and financing Kenya's investment needs". A well-functioning financial system according to Kenya vision 2030 is critical to accelerating economic growth as it will ensure macroeconomic stability and promote private sector development, which in turn will generate employment opportunities and reduce poverty. A sound financial sector will also encourage Foreign Direct Investment, safeguard the economy from external shocks as well as propel Kenya to become a leading financial centre. The Financial Services sector is thus anticipated to play a key role in mobilizing the savings and investments required to implement the Flagship Projects estimated at USD. 6.5 billion, and expected to be financed by Government of Kenya and both local and foreign private investors. The vision's goal is to increase savings and investment rates 
from $14 \%$ to between $25 \%$ and $30 \%$ of gross domestic product and raise capitalization from $50 \%$ to $90 \%$ of gross domestic product, hence providing an avenue for the corporations/companies and the government to raise funds for the purpose of business expansion and development of projects.

In the endogenous growth literature, the link between either stock market liquidity or development and economic growth for developed economies has received much attention. Studies also exist on the causality between economic growth and stock market development. However, there are very few studies on developing economies and most have yielded mixed results. In an emerging market economy like Kenya, there is scarcity of literature on (1) how market liquidity affects growth, and (2) the relationship between economic growth and stock market development.

The main objective of this study is to determine whether stock market development as measured by trade volume and/or market capitalization leads to growth of Kenya's economy as envisioned in the Vision 2030. Specifically the paper seeks to investigate the correlation between economic growth and stock market capitalization in Kenya as well as the correlation between economic growth and stock market trade volume in Kenya. We also seek to establish the direction of causality between economic growth and stock market development.

\section{Literature Review}

In recent years, an increasing amount of interest has been dedicated to the relationship between economic development and financial markets. New insights in the theory of finance or growth have spurred renewed research interests in establishing a link either between "growth and finance" or "finance and development", due to a large amount of empirical studies demonstrating a clear positive correlation between economic and financial markets development indicators.

Capital market theory suggests that external financing constraints faced by firms are eased by a developed financial system that illuminates a mechanism through which economic growth is influenced. Further, Levine (1991) suggests that stock market development reduces both productivity shocks and liquidity, and in turn leads to higher growth in the economy. "Theory and empirical evidence make it difficult to conclude that financial development is an inconsequential addendum to the process of economic growth or that the financial system merely and automatically responds to economic activity" (Levine, 2005, p.921). Since the late 1970s, growth theory has been regarded as the most appropriate approach to the theory of development as opposed to a narrow, explicit approach formulated by an earlier branch of economics such as Myrdal, Hirschmann and Lewis.

Atje and Jovanovic (1993), Caporale, Howells and Soliman (2004), Levine (1997), Levine and Zervos (1998), Rajan and Zingales (1998), Demirgüç-Kunt and Levine (1996), Brasoveanu, Dragota, Catarama, \& Semenescu (2008) and Nurudeen (2009) conclusively established through their empirical studies, the existence of a direct relationship between economic growth and capital market development.

The positive correlation between economic growth and financial system development can be measured via variables that capture the level of financial asset formation in the banking system (King \& Levine, 1993) and/or via stock market development indicators like size, liquidity and risk diversification (Levine \& Zervos, 1998; Atje \& Jovanovic, 1993). Graff (2003) provided empirical evidence suggesting that the characterization of the finance-growth nexus was appropriate given that finance matters for growth, and that causation runs largely from financial to economic growth with little evidence of mutual causation and no evidence of reverse causation. Caporale et al (2004) performed causality tests in a bivariate context, looking for causal links between domestic credit, prevalence of bank deposits and economic growth and found little evidence of causality, a strong support for a causal link between finance and growth. They also tested for causality in a trivariate context and established causality between economic growth and financial development; and recognized stock market development as the measure that led to change of results.

Calderon and Liu (2003), studying the direction of causality between finance and growth, concluded that financial system development generates economic growth, with a stronger causal relation being in the emergent countries and being explained by a fast accumulation of capital and productivity growth. Rajan and Zingales (1998) emphasized that financial development is a prediction element for growth; given that the stock market reflects the present value of future growth opportunities and that the ex-ante development of the markets facilitates the ex-post economic growth of the external financing dependent sectors.

Stock market capitalization refers to the combined value of all company's outstanding shares listed in a national stock exchange. Brasoveanu et al (2008) using linear regression proved that market capitalization and the economic growth are strongly correlated for Romania, an indication that the structure of the market index is similar to the GDP and that capital market is efficient, a contradiction given that the Romanian market is 
assumed inefficient and the market index structure does not follow the GDP structure. Nurudeen (2009) using correction analysis, established a strong positive link between market capitalization, GDP growth and gross domestic saving. Ewah, Esang \& Bassey (2009) using multiple regression analysis established that interest rate, government stock and market capitalization are significant stock market variables that are capable of influencing economic growth. Levine and Zervos (1998) established that capitalization is not robustly correlated with capital accumulation, productivity improvements or economic growth; and argued that it is not the volatility or size of the stock market, but the ease with which shares can be traded, that matters for growth. These findings are consistent with theory, as it is the ability to trade the economy's productive technologies easily that influences resource allocation and growth and not by simply listing on an exchange.

Market liquidity refers to the ease with which one is able buy and sell financial assets in the market, without adversely affecting the price, and best expressed as a ratio of value of shares traded to size of the economy. Market liquidity captures the aspects of immediacy, breadth, depth, and resilience in markets. The more liquid the markets are the better, given that liquid markets may make participants take on more risk with an assumption that they can liquidate their positions quickly and at fairly predictable prices. A stock market with a high degree of turnover is said to be highly liquid. Economists have debated for a long time on whether developing countries should seek to promote liquid stock markets as a means of advancing economic growth due to its considerable policy relevance with conflicting results. Levine and Zervos (1998) established that stock market liquidity is a robust predictor of physical capital, productivity and real per capita GDP growth.

Empirical evidence strongly supports the belief that greater stock market liquidity boosts, or at least precedes economic growth. Levine (1991) empirically investigated whether measures of stock market liquidity, size, volatility, and integration with world capital markets are robustly correlated with current and future rates of economic growth, capital accumulation, productivity improvements, and saving rates using panel data and established that stock market liquidity-as measured both by the value of stock trading relative to the size of the market and by the value of trading relative to the size of the economy-is positively and significantly correlated with current and future rates of economic growth, capital accumulation, and productivity growth.

Mwaura, Ngugi, \& Njenga (2000) established that the level of stock returns influences the volume of trading activities and enhances transparency in the price discovery process by increasing investors' participation, while taxation policy plays a major role in facilitating share trading if aimed at reducing transaction costs and ensuring competitiveness of shares among financial assets. Zhu, Ash, \& Pollin (2002) replicated the Levine and Zervos (1998) research and established that after controlling for outliers, the conclusion that countries operating more liquid stock markets enjoy a faster economic growth was no longer tenable. Zhu et al (2002) established from literature that countries that operated strong government-administered systems of financial regulation and credit allocation played a major role in establishing credit flows to productive investments hence affecting the flow of funds for investment. Therefore, Zhu et al (2002) replication of the Levine-Zervos model suggested that the unique financial structure was the primary force establishing the positive and significant correlation that was observed between stock market turnover and GDP growth in the overall 47-country sample, beyond which results led to the conclusion that, at least for the 1976-93 period under consideration, no statistically reliable relationship operated at all between the level of stock market turnover within countries in the sample and these countries' aggregate economic performance as measured by GDP growth.

It is expected that growth in market capitalization and trade volume leads to stock market development and further influences economic growth. The correlation between stock market development and economic growth is expected to be positive with feed-back-effect. The strongest link is expected from economic growth to stock market development suggesting that stock market development follows economic growth. Economic growth causes financial institutions to change and develop.

\section{Data and Methodology}

The research seeks to empirically establish whether the development of Nairobi Securities Exchange affects economic growth in Kenya. Linear regression methods are used to analyze the quantitative effects of stock market development on economic growth as used by Brasoveanu et al (2008) with necessary adaptation to fit into Kenyan data. Quarterly time series data on gross domestic product, market capitalization and trade volume covering the years 2000 to mid 2011, a total of 46 observations were used. Data was checked for reliability, suitability and adequacy through various statistical procedures, to avoid spurious results. The main source of data was Nairobi Securities Exchange, Kenya National Bureau of Statistics and Capital Markets Authority, as these sources contain the most detailed and reliable collection of development data in Kenya.

Brasoveanu et al (2008) analyzed the link between the capital market and the economic growth in Romania on 
quarterly data of 26 observations. They characterized the capital market and economic growth using the real market capitalization, computed in order to eliminate the inflation effect; the real trade volume, as a measure of the market size and liquidity; a liquidity proxy, computed as the number of traded shares divided by the number of listed shares and analyzed the correlation between economic growth and capital market development using linear regression and vector autoregressive methods. In their models, the authors expressed economic growth as a function of market capitalization, trade volume and liquidity proxy. Thus, in this study we specify our econometric model as:

$$
\log \left(G D P_{t}\right)=\beta_{0}+\beta_{1} \log \left(S M C_{t}\right)+\beta_{2} \log \left(S T V_{t}\right)+\varepsilon_{t}
$$

where GDP is gross domestic product, SMC stock market capitalization, and STV stock market trade volume.

Table 1. Variables used and their definitions

\begin{tabular}{cc}
\hline Variable & Definition \\
\hline $\begin{array}{c}\text { Stock Market } \\
\text { Capitalization } \\
\text { (SMC) }\end{array}$ & $\begin{array}{c}\text { Market capitalization equals the current value of all company's shares listed on } \\
\text { domestic exchanges, and is used to measure the size of the stock market and is also an } \\
\text { indicator of market development. }\end{array}$ \\
$\begin{array}{c}\text { Gross Domestic } \\
\text { Product (GDP) }\end{array}$ & $\begin{array}{c}\text { GDP is the monetary value of all finished goods and services produced within a } \\
\text { country's borders, with its real growth rate being used as a measure of the economic } \\
\text { growth. }\end{array}$ \\
$\begin{array}{c}\text { Stock market Trade } \\
\text { Volume (STV) }\end{array}$ & $\begin{array}{r}\text { Trade volume refers to the value of shares traded in a stock exchange and is used as a } \\
\text { measure of the market liquidity, and also of the market size. }\end{array}$ \\
\hline
\end{tabular}

\section{Results and Discussion}

\subsection{Data Analysis and Interpretation}

The first step is to conduct the stationarity (unit root) test on the variables. This is achieved by employing the Augmented Dicker-Fuller (ADF) statistic. The result of the stationarity test is shown in table 2 below:

Table 2. Stationarity tests (first difference)

\begin{tabular}{cccc}
\hline Variables & ADF-statistic & Prob. & Conclusion \\
\hline $\log \left(\mathrm{GDP}_{\mathrm{t}}\right)$ & -10.6919 & 0.0000 & Stationary \\
$\log \left(\mathrm{SMC}_{\mathrm{t}}\right)$ & -3.6300 & 0.0008 & Stationary \\
$\log \left(\mathrm{STV}_{\mathrm{t}}\right)$ & -4.3108 & 0.0001 & Stationary \\
\hline
\end{tabular}

The unit root test results indicate that all variables, that is $\log (\mathrm{GDP}), \log (\mathrm{SMC})$ and $\log (\mathrm{STV})$ are stationary at the first difference and $1 \%$ level of significance. This confirms that they have a long term relationship and regression gives good results.

\section{Test for Causality}

Next, we conducted a causality test, to confirm whether a bi-directional (feedback) or unidirectional relationship existed between the variables - stock market capitalization, stock trade volumes and economic growth. To achieve this, granger-causality statistic was used with four lags.

Table 3. Pair wise granger causality test results

\begin{tabular}{ccccc}
\hline Null Hypotheses & Obs. & F- Statistic & Prob. & Conclusion \\
\hline SMC does not Granger Cause GDP & 46 & 2.6761 & 0.0489 & causality \\
GDP does not Granger Cause SMC & 46 & 5.7219 & 0.0013 & causality \\
STV does not Granger Cause GDP & 46 & 2.3662 & 0.0730 & causality \\
GDP does not Granger Cause STV & 46 & 3.2431 & 0.0238 & causality \\
STV does not Granger Cause SMC & 46 & 2.3264 & 0.0768 & causality \\
SMC does not Granger Cause STV & 46 & 3.2998 & 0.0221 & causality \\
\hline
\end{tabular}


We reject the null hypotheses in all three scenarios as shown above and conclude that Granger causality runs both-ways in all the three scenarios. The results therefore indicate that the bi-directional (feedback) effects exist between all variables.

The regression models were subjected to a series of diagnostic tests, including ARCH (Note 1), normality (Note 2 ) and stability (Note 3 ) tests. The tests confirmed that the data was normally distributed with no autocorrelation or partial autocorrelations. Further, the estimated regression equations were stable throughout the sample with no structural changes and all recursive residuals plot were within the standard error bands signifying stability in the parameters.

Three selected regression models yielded the following results after including a control variable (inflation) and a dummy to eliminate the seasonal effect noticed in the second quarter.

Table 4. Regression results

\begin{tabular}{|c|c|c|c|c|c|c|}
\hline \multirow[b]{3}{*}{ Independent Variables } & \multicolumn{6}{|c|}{ Dependent Variable } \\
\hline & \multicolumn{2}{|c|}{$\mathrm{R} 1-\log \left(\mathrm{GDP}_{\mathrm{t}}\right)$} & \multicolumn{2}{|c|}{$\mathrm{R} 2-\log \left(\mathrm{STV}_{\mathrm{t}-4}\right)$} & \multicolumn{2}{|c|}{$\mathrm{R} 3-\log \left(\mathrm{SMC}_{\mathrm{t}}\right)$} \\
\hline & coefficient & t-value & coefficient & t-value & coefficient & $\mathrm{t}$-value \\
\hline $\log \left(\mathrm{SMC}_{\mathrm{t}}\right)$ & $0.1152 *$ & 6.8788 & $0.8550 *$ & 2.8765 & & \\
\hline $\log \left(\mathrm{STV}_{\mathrm{t}-4}\right)$ & $0.0246^{* *}$ & 2.2669 & & & & \\
\hline $\log \left(\mathrm{STV}_{\mathrm{t}}\right)$ & & & & & $0.3697 *$ & 14.9671 \\
\hline $\log \left(\mathrm{GDP}_{\mathrm{t}}\right)$ & & & $3.5217 * *$ & 1.8873 & $2.9686^{*}$ & 12.6091 \\
\hline $\operatorname{Inf}_{\mathrm{t}}$ & $-0.3955^{*}$ & -2.7072 & 2.1194 & 0.9554 & $1.4847^{*}$ & 3.9868 \\
\hline $\mathrm{D}$ & $-0.0613 *$ & -4.0929 & & & $0.1916^{*}$ & 4.7931 \\
\hline $\mathrm{C}$ & $10.9771^{*}$ & 78.918 & $-47.142 * *$ & -2.3461 & $-28.0054^{*}$ & -10.0363 \\
\hline Adjusted $\mathrm{R}^{2}$ & 0.90856 & & 0.8112 & & 0.9862 & \\
\hline \multirow[t]{3}{*}{ F-statistic } & 102.8394 & & 59.7054 & & 803.808 & \\
\hline & \multicolumn{6}{|c|}{ Tests } \\
\hline & coefficient & $\mathrm{p}$-value & coefficient & $\mathrm{p}$-value & coefficient & $\mathrm{p}$-value \\
\hline ARCH Test (lag1) & 0.1535 & 0.6952 & 5.6496 & 0.1300 & 1.2118 & 0.2710 \\
\hline White Heteroskedasticity Test & 8.3255 & 0.3048 & 7.7943 & 0.2536 & 7.0799 & 0.4206 \\
\hline Jarque-Bera & 2.1938 & 0.3339 & 1.9429 & 0.3785 & 0.8853 & 0.6423 \\
\hline
\end{tabular}

Note: $* * *$ significant at $10 \%, * *$ significant at $5 \%$ and $*$ significant at $1 \%$.

\section{Interpretation of the Regression Equations}

$$
(R 1) \sim \log (G D P t)=10.977+0.1152 \log (S M C t)+0.0246 \log \left(S T V_{t-4}\right)-0.3962 \operatorname{Inf}_{t}-0.0613 D
$$

The coefficients $\beta_{1}$ and $\beta_{2}$ are both positive and significantly different from zero at $1 \%$ and $5 \%$ level of significance respectively, an indication that $\log \left(\mathrm{SMC}_{\mathrm{t}}\right)$ and $\log \left(\mathrm{STV}_{\mathrm{t}-4}\right)$ are important determinants of $\log \left(\mathrm{GDP}_{\mathrm{t}}\right)$ and they are positively correlated. Further, a $1 \%$ increase in both $\log \left(\mathrm{SMC}_{\mathrm{t}}\right)$ and $\log \left(\mathrm{STV}_{\mathrm{t}-4}\right)$ causes $0.115 \%$ and $0.025 \%$ increase in $\log \left(\mathrm{GDP}_{\mathrm{t}}\right)$ respectively. The independent variables jointly explain $91 \%$ of the variations in $\log \left(\mathrm{GDP}_{\mathrm{t}}\right)$ as shown by the equation's adjusted $\mathrm{R}^{2}$ of 0.909 . The results therefore confirm that economic growth (measured by $\log (\mathrm{GDP})$ ) is positively correlated with stock market development (measured by $\log (\mathrm{SMC})$ and the fourth lag of $\log (\mathrm{STV})$ ). The results are consistent with developed economies where market indexes are similar to GDP structures and stock markets are efficient.

$$
(R 2) \sim \log \left(S T V_{t-4}\right)=-47.1418+0.85495 \log \left(S M C_{t}\right)+3.5217 \log \left(G D P_{t}\right)+2.1194 \operatorname{Inf}_{t}
$$

The coefficients $\beta_{1}$ and $\beta_{2}$ are both positive and significantly different from zero at $1 \%$ and $10 \%$ level of significance respectively; this confirms that $\log \left(\mathrm{SMC}_{\mathrm{t}}\right)$ and $\log \left(\mathrm{GDP}_{\mathrm{t}}\right)$ are important determinants of $\log \left(\mathrm{STV}_{\mathrm{t}-4}\right)$, and they are positively correlated. Further, a $1 \%$ increase in both $\log \left(\mathrm{SMC}_{\mathrm{t}}\right)$ and $\log \left(\mathrm{GDP}_{\mathrm{t}}\right)$ causes a $0.86 \%$ and $3.52 \%$ increase in $\log \left(\mathrm{STV}_{\mathrm{t}-4}\right)$ respectively. The independent variables jointly explain $81 \%$ (adjusted $\mathrm{R}^{2}$ equals $0.811)$ of the variations in $\log \left(\mathrm{STV}_{\mathrm{t}-4}\right)$. The strong correlation between both $\log \left(\mathrm{SMC}_{\mathrm{t}}\right)$ and $\log \left(\mathrm{GDP}_{\mathrm{t}}\right)$ with $\log \left(\mathrm{STV}_{\mathrm{t}-\mathrm{A}}\right)$ confirms that growth in trade volume (measured by $\left.\log \left(\mathrm{STV}_{\mathrm{t}-4}\right)\right)$, is as a result of growth in market capitalization (measured by $\log (\mathrm{SMC})$ ) and economic growth (measured by $\log (\mathrm{GDP})$ ). The results therefore confirm that stock market development is strongly correlated with economic growth. This confirms feedback effects between the stock market development and economic growth.

$(R 3) \sim \log \left(S M C_{t}\right)=-28.005+0.36966 \log \left(S T V_{t}\right)+2.9686 \log \left(G D P_{t}\right)+1.4847$ Inf $_{t}+0.1916 D$

The coefficients $\beta_{1}$ and $\beta_{2}$ are both positive and significantly different from zero at $1 \%$ and $10 \%$ level of 
significance respectively; hence we conclude that $\log \left(\mathrm{STV}_{\mathrm{t}}\right)$ and $\log \left(\mathrm{GDP}_{\mathrm{t}}\right)$ are important determinants of $\log \left(\mathrm{SMC}_{\mathrm{t}}\right)$ and they are positively correlated. A $1 \%$ increase in both $\log (\mathrm{STVt})$ and $\log (\mathrm{GDPt})$ causes $0.37 \%$ and $3 \%$ increase in $\log (\mathrm{SMCt})$ respectively. The equation's adjusted $\mathrm{R}^{2}$ equals 0.986 , an indication that independent variables jointly explain $98.6 \%$ of the variations in $\log (\mathrm{SMCt})$. The strong positive correlation between both trade volume and economic growth with market capitalization confirms that growth in market capitalization (measured by $\log (\mathrm{SMC})$ ), is as a result of growth in trade volumes (measured by $\log (\mathrm{STV})$ ) and economic growth (measured by $\log (\mathrm{GDP})$ ). This further confirms feedback effects between the three variables.

\section{Summary and Conclusions}

The research has established that all the three variables i.e. $\log (\mathrm{GDP}), \log (\mathrm{SMC})$ and $\log (\mathrm{STV})$ are stationary with no autocorrelation or heteroskedasticity and are normally distributed. Furthermore, the regression equations have no structural change and Granger causality runs both-ways; a case of bi-directional behaviour (feedback effects) between all variables.

The variables $\log \left(\mathrm{SMC}_{\mathrm{t}}\right)$ and $\log \left(\mathrm{STV}_{\mathrm{t}-4}\right)$ are important determinants of $\log \left(\mathrm{GDP}_{\mathrm{t}}\right)$ and are positively correlated to economic growth with adjusted $\mathrm{R}^{2}$ of 0.909 . The results confirm that economic growth (measured by GDP) is positively correlated with stock market development (measured by SMC and the fourth lag of STV). The stock trade volume only gives meaningful results at the fourth lag, perhaps due to the illiquidity nature of the Kenyan stock market.

The increasing importance of financial markets prompted the researchers to examine the effects of stock market development on economic growth. The present study is an attempt to investigate this relationship of stock market development and economic growth by taking size and liquidity of NSE as independent variables. The time series quarterly data for the period 2000 to mid 2011 reveals existence of a strong correlation between economic growth and stock market development vis-à-vis market capitalization and trade volume in Kenya. Market capitalization and stock trade volume are therefore important stock market variables that are capable of influencing economic growth in Kenya. However, stock market size, as measured by market capitalization, has a stronger influence on economic growth than stock market liquidity in Kenya may be due to market illiquidity.

The empirical results therefore confirm that the stock market development is positively correlated with economic growth in Kenya with feed-back effect. Further, these findings are consistent with the findings of Levine (1997), Atje and Jovanovic (1993), Levine and Zervos (1998), Demirgüç-Kunt and Levine (1996), Rajan and Zingales (1998), Caporale et al (2004), Nurudeen (2009) and Brasoveanu et al (2008) who conclusively documented a direct link between economic growth and stock market development. It has been empirically established that economic growth is positively impacted by stock market development as assumed by the Government of Kenya Vision 2030 blue print and its development leads to increased economic development as envisioned.

\section{References}

Atje, R., \& Jovanovic, B. (1993). Stock markets and development. European Economic Review, 37(2-3), 632640. http://dx.doi.org/10.1016/0014-2921(93)90053-D

Brasoveanu, L. O., Dragota, V., Catarama, D., \& Semenescu, A. (2008). Correlations between capital market development and economic growth: The case of Romania. Journal of Applied Quantitative Methods, 3(1), $64-75$.

Calderon, C., \& Liu, L. (2003). The direction of causality between financial development and economic growth. Journal of Development Economics, 72(1), 321-334. http://dx.doi.org/10.1016/S0304-3878(03)00079-8

Caporale, G. M., Howells, P. A., \& Soliman, A. M. (2004). Stock market development and economic growth: The causal linkage. Journal of Economic Development, 29(1), 33-50.

Carlin, W., \& Mayer, C. (2003). Finance, investment, and growth. Journal of Financial Economics, 69(1), 191226. http://dx.doi.org/10.1016/S0304-405X(03)00112-0

Demirgüç-Kunt, A., \& Levine, R. (1996). Stock market development and financial intermediaries: Stylised facts. World Bank Economic Review, 10(2), 291-321.

Ewah, S. O., Esang, A. E., \& Bassey, J. U. (2009). Appraisal of capital market efficiency on economic growth in Nigeria. International Journal of Business \& Management, 4(12), 219-228.

Graff, M. (2003). Financial development and economic growth in corporatist and liberal market economies. Emerging Markets Finance \& Trade, 39(2), 47-69.

King, R. G., \& Levine, R. (1993). Finance and growth: Schumpeter might be right. Quarterly Journal of 
Economics, 108(3), 717-738. http://dx.doi.org/10.2307/2118406

Levine, R. (1991). Stock markets, growth, \& tax policy. Journal of Finance, 46(4), 1445-65. http://dx.doi.org/10.1111/j.1540-6261.1991.tb04625.x

Levine, R. (1997). Financial development and economic growth: Views and agenda. Journal of Economic Literature, 35(1), 688-726.

Levine, R. (2005). Finance and growth: Theory and evidence. In P. Aghion, \& S. Durlauf (Eds.), Handbook of economic growth (pp. 865-934). Elsevier.

Levine, R., \& Zervos, S. (1998). Stock markets, banks, and economic growth. American Economic Review, 88(3), 537-58.

Mwaura, M., Ngugi, R., \& Njenga, G. (2000). Financial sector development and economic growth for African countries. KIPPRA Discussion Paper No. 99, Nairobi.

Nurudeen, A. (2009). Does stock market development raise economic growth? Evidence from Nigeria. The Review of Finance and Banking, 1(1), 15-26.

Rajan, R. G., \& Zingales, L. (1998). Financial dependence and growth. American Economic Review, 88, 559586.

Zhu, A., Ash, M., \& Pollin, R. (2002). Stock market liquidity and economic growth: A critical appraisal of the Levine/Zervos Model. University of Massachusetts Amherst.

\section{Notes}

Note 1. The Auto Regressive Conditional Heteroscedasticity (ARCH) test was used to test whether the time series data exhibit time-varying volatility clustering for regression equations R1, R2 and R3, and gave probabilities which are more than 0.1 ; hence at $1 \%$ level of significance, we cannot reject the null hypotheses of no $\mathrm{ARCH}$ in the residuals. Thus, we concluded that there was no autocorrelation or partial autocorrelation at all lags in the data sets, and that the Q-statistics is insignificant.

White heteroskedasticity test with no cross terms was used to test for Heteroskedasticity and gave a probability of more than ten percent for all the three regression equations; hence cannot reject the null hypotheses of no Heteroscedasticity.

Note 2. The Jarque-Bera statistic was used to test for normality and gave a probability of more than 0.1 for all the three regression equations; hence cannot reject the null hypotheses that the data is normally distributed. The residuals are therefore assumed to be normally distributed, given the statistically insignificant Jarque-Bera statistic in all equations.

Note 3. Chow Breakpoint Test was used to examine whether the model parameters were stable across several subsamples in the data; and the results show that in all selected breakpoint, test statistics do not reject the null hypotheses of no structural change in the regression function. Further, a plot of the recursive residuals shows no residuals outside the standard error bands suggesting stability in the parameters.

\section{Copyrights}

Copyright for this article is retained by the author(s), with first publication rights granted to the journal.

This is an open-access article distributed under the terms and conditions of the Creative Commons Attribution license (http://creativecommons.org/licenses/by/3.0/). 